\title{
SPOŁECZNE ZAKORZENIENIE ARCHITEKTURY NA PRZYKŁADZIE XVII-WIECZNEJ SYNAGOGI W ZAMOŚCIU
}

\author{
Wiktoria Morawska \\ Instytut Socjologii, Centrum Studiów Niemieckich i Europejskich im. Willy Brandta, \\ Uniwersytet Wrocławski, ul. Strażnicza 1-3, 50-206 Wrocław \\ E-mail: wiktoria.morawskapp@gmail.com \\ ORCID iD: https://orcid.org/0000-0002-4043-5290
}

\begin{abstract}
Abstrakt
Teza. Celem artykułu jest wskazanie społecznego zakorzenienia architektury synagogalnej na przykładzie XVII-wiecznej bóżnicy w Zamościu. Analiza stanowi próbę wykazania związku między usytuowaniem zabytku w strukturze urbanistycznej a przeżyciami mniejszości, historią losów społeczności i gminy żydowskiej na terenie miasta.

Omówione koncepcje. Z uwagi na charakter podjętego tematu analiza była oparta na badaniach archiwaliów, co stanowi podstawową metodę pracy w ramach dyscypliny historii sztuki. Oprócz studiów materiałów inwentaryzatorskich i samego obiektu w treści artykułu odnoszono się do tez najważniejszych badaczy i badaczek architektury synagogalnej i urbanistyki w Polsce: E. Bergman, J. Jagielskiego, A. Łupienko, A. Zabłockiej-Kos, K. Matyjaszka, M. oraz K. Piechotków.

Wyniki i wnioski. Analiza wykazała błędność dotychczasowych interpretacji stylistyki synagogi w Zamościu jako sefardyjskiej. Wysuwa się wniosek, że wzorem była - oprócz wcześniejszych bożnic, w których stosowano centralizację głównej sali modlitewnej i podobny układ - architektura kościelna z obszaru Ordynacji Zamojskiej. Świadczy o tym m.in. implikowanie detalu stosowanego w ramach typu kalisko-lubelskiego. Wątek ten wysuwa się także jako nowy problem badawczy, który, jak do tej pory, nie został opisany w kontekście budownictwa judaizmu.

Jednocześnie wskazuje się na szeroki kontekst społeczny, w którym istnieje przedreformacyjna architektura synagogalna. Przełom XVI i XVII w. był czasem kreowania nowych form w obrębie budownictwa żydowskiego w Polsce i tzw. Złotym Wiekiem Żydów Polskich. Jest to odwrotna tendencja od krajów Europy Zachodniej, z których wysiedlono społeczność żydowska, a rozwój budowlany został wstrzymany.

Wartość poznawcza podejścia. Największą wartość stanowi oryginalna, dotychczas niepodejmowana próba wdrażania dyskursu krytycznego wobec silnie rozpowszechnionej teorii ciągłości tradycji hiszpańskiej w ramach architektury bóżnic. Jednocześnie $\mathrm{w}$ artykule zaprezentowano dyrektywę metodologiczną $\mathrm{w}$ ramach której zakłada się, że w historii architektury priorytetem nie jest tylko uwzględnianie ergonomiczności, ale warunków społeczno-kulturowych, w których budowla istnieje. Oznacza to potrzebę interdyscyplinarnej analizy dzieła sztuki, w której uwzględnia
\end{abstract}


się nie tylko opis formy, ale interpretację znaczenia, które metaforycznie ma ",nosic'” realizowany obiekt.

Słowa kluczowe: architektura, synagogi, bożnice, socjologia miasta, Zamość, renesans, wschodnia polska

Social rooting of architecture on the example of 17th century synagogue in Zamość (Poland)

Abstract

Argument. The aim of the article is to show the social roots of synagogue architecture through the example of the 17th century synagogue in Zamośc. This analysis is an attempt to show the relationship between the location of the building in the urban structure and the experiences of minorities, the history of the social group and the Jewish community in the city.

Concepts discussed. Due to the nature of the topic, the analysis was based on research among archival materials, which is the basic method of working within the discipline of art history. In addition to studying the inventory materials and the object itself, the content of the article also refers to the theses of the most important researchers of synagogue architecture and town planning in Poland: E. Bergman, J. Jagielski, A. Łupienko, A. Zabłocka-Kos, K. Matyjaszka, M. and K. Piechotka.

Results and conclusions. The analysis revealed that the previous interpretations of the style of the synagogue in Zamość as Sephardic were incorrect. The conclusion is that the model was - apart from earlier synagogues, which used the centralization of the main prayer hall and a similar layout - based on church architecture from the area of the Zamość Estate. This is evidenced by, amongst others, the implication of the detail used within the Kalisz-Lublin type. This theme also emerges as a new research problem, which has hitherto not been described in the context of the architecture of Judaism.

At the same time, it points to the broad social context in which pre-reform synagogue architecture exists. The turn of the 16th and 17th centuries was the time of creating new forms in the area of Jewish building construction in Poland and the so-called Golden Age of Polish Jews. This is the reverse of the tendency in Western European countries, from which the Jewish community was displaced and construction development halted.

Cognitive value of the approach. The greatest value is the original attempt, as yet not undertaken, to implement a critical discourse in the face of the strong widespread theory of the continuity of the Spanish tradition within the architecture of synagogues. At the same time, the article presents a methodological guideline under which it is assumed that in the history of architecture the priority is not only to take into account ergonomics, but also the socio-cultural conditions in which a building exists. This signifies the need for an interdisciplinary analysis of a work of art, which takes into account not only a description of the form, but also an interpretation of the meaning which the object realized metaphorically "carries".

Key words: architecture, synagogue, urban sociology, Zamość, renaissance, eastern Poland 


\section{WPROWADZENIE}

Synagogi, traktowane zarówno jako świadectwa historii Żydów w Polsce, „lustro” w którym widać odwrócony obraz miejskich symboli polskości (Matyjaszek, 2019), jak i zabytki - dzieła sztuki, są obecne w dyskursie naukowym, jak i świadomości części z mieszkańców miast, gdzie owe obiekty się znajdują. Prawdą jest jednak, że funkcję synagogi może pełnić każdy budynek, w którym zbierze się minjan, czyli dziesięciu mężczyzn, którzy ukończyli trzynasty rok życia (Bergman, 1996). Oznacza to, że wygląd i rozwiązania architektoniczne mają stanowić wartość dodaną: o funkcji wyłącznie estetycznej. Mimo tego na terenie Polski w ciągu ostatnich stuleci powstało wiele synagog, w których dążono do nowych rozwiązań architektonicznych, wysokiego poziomu dekoracji malarskiej i rzeźbiarskiej, czy wdrażania złożonej symboliki.

Celem niniejszego artykułu jest omówienie powyższej problematyki we wschodniej Polsce na przykładzie XVII-wiecznej synagogi przy ulicy Ludiwka Zamenhofa 9 (Pereca 14) w Zamościu. Obiekt ten został wzniesiony w latach 1610-1618 (Kuwałek, Litwin, 2011) lub 1610-1620 (Bergman, Jagielski, 1996) w drugim bloku od rynku głównego jako budowla jednoprzestrzenna z dobudowanymi - od strony północnej i południowej - w 1. 30. XVII w. (Kuwałek, Litwin, 2011) babińcami: aneksami przeznaczonymi dla kobiet.

Tak usystematyzowana tematyka pracy wiąże się z dyrektywą metodologiczną zakładającą potrzebę interdyscyplinarnej analizy dzieła sztuki, która pośrednio będzie widoczna w moim artykule. Podjęłam starania uwzględnienia związku pomiędzy warunkami i klimatem społecznym, w którym powstaje dzieło, jego formą i znaczeniem, które metaforycznie ma „nosić” realizowany obiekt, jak i wpływem na budowanie współczesnej tożsamości nie tylko Żydów Zamojszczyzny, ale też w ogóle mieszkańców Zamościa.

\section{Historyczne uWARUNKowania POWSTANia SYNAgogi w Zamościu - \\ SPOŁECZNOŚĆ I GMINA ŻYDOWSKA NA TERENIE MIASTA}

Od czasu działalności chicagowskiej szkoły socjologii - nurtu końca XIX wieku i początku XX - a szczególnie od powojennych badań polskiego socjologa Aleksandra Wallisa zakłada się, że miasto jest skomplikowaną przestrzenią społecznych wpływów uwikłanych w szeroki kontekst znaczeń (Łupienko, Zabłocka-Kos, 2019). Oznacza to, że nie tylko techniczne myślenie o ergonomicznej przestrzeni stanowi punkt wyjścia, ale kultura i społeczeństwo, $\mathrm{w}$ ramach którego dzieło jest tworzone. Czynniki te miały szczególny wpływ na architekturę synagogalną w Zamościu.

Tereny Rzeczpospolitej w XVI wieku były zamieszkiwane przede wszystkim przez Aszkenazyjczyków - Żydów wywodzących się z Niemiec i zazwyczaj posługujących się językiem jidysz (Piechotek, 1999). Jednak Zamość był miastem odmiennym. Wśród przyczyn odrębności można wymienić: renesansowy charakter urbanistyki miejskiej według projektu włoskiego architekta Bernardo Morando (Kuwałek, Litwin, 2011), nawiązania do architektury Padwy - w której studiował Jan Zamoyski - traktowanie miasta jako stolicy regionu (Kozakiewicz, 1978). Oprócz powyższych można wydzielić trzy główne konteksty, w które metaforycznie „uwikłana” jest zamojska synagoga.

Pierwszym i najważniejszym determinantem odrębności Zamościa jest zjeżdżająca do miasta ludność. W tym miejscu należy uwzględnić, że Żydzi na ziemiach wschod- 
niej Polski, Lubelszczyzny, pojawili się dużo później niż w pozostałych regionach. Przed XVI w. tylko pojedyncze miasta - do których zaliczyć można Lublin i Kazimierz - były zamieszkiwane przez społeczność żydowską (Trzciński, 1990, 6). Wraz z migracjami na teren Zamościa powiększała się społeczność Sefardyjczyków Żydów przybywających na tereny ówczesnej Polski od około 1492 roku (Piechotkowie, 1999). Wywodzili się oni z Hiszpanii lub Portugalii i posługiwali się dialektem judeo-romańskim. Wcześniej żadna z gmin tego nurtu nie działała na terenie Rzeczypospolitej. Pojawienie się Sefardyjczyków na terenie Zamościa wpłynęło na swoistą hybrydalność zbudowanej tam synagogi, a przyczyny napływu tej społeczności na teren miasta zostaną omówione w kolejnych częściach artykułu.

W tym miejscu należy wskazać, że istnienie dwóch, odrębnych społeczności miało znaczący wpływ na rozwój architektury. Jak wskazują Maria i Kazimierz Piechotkowie, stała wymiana myśli teologicznej oparta na różnicy poglądów między Sefardyjczykami a Aszkenazyjczykami, wpłynęła na formowanie się nowych typów przestrzennego układu głównej sali modlitewnej. Jest to widoczne przede wszystkim w miastach północnowłoskich i na terenie Rzeczpospolitej (Kuwałek, Litwin, 2011). Zjawisko to jeszcze silniej uwypukla wyjątkowość budownictwa synagogalnego na tym terenie.

Jako drugi aspekt odmienności miasta wymienić można fakt, że okres przybycia Sefardyjczyków do Zamościa - pomiędzy II połową XVI a I połową XVII w. - nazywany jest „złotym wiekiem Żydów polskich” (Kuwałek, Litwin, 2011). Wynikało to z korzystnej sytuacji Polski pod panowaniem Jagiellonów oraz przywilejów nadanych po unii realnej Korony Królestwa Polskiego i Wielkiego Księstwa Litewskiego w 1569 r. Nadane uprawniania były wyjątkowe na tle innych krajów Europy, gdzie utrzymały się jedynie nieliczne, aszkenazyjskie gminy żydowskie. W efekcie początek XVII w. był czasem dynamicznego rozwoju kultury żydowskiej, w tym aktywnej działalności drukarni publikujących $\mathrm{w}$ języku jidysz i hebrajskim, ale przede wszystkim zmian $\mathrm{w}$ formach i unowocześnienia architektury żydowskiej.

W tym korzystnym dla społeczności żydowskiej czasie w Zamościu - na mocy przyzwolenia J. Zamoyskiego z 1588 roku - powstała jedyna w Polsce gmina (kahał) sefardyjska (Bilewicz, 2012). O uzyskanie przywileju starał się przez dwa lata Mosze de Mosse Cohena, który podjął działania jako reprezentant Zydów sefardyjskich (Baranowscy, 1967). Wcześniej prawo do posiadania modlitewni żydowskich gwarantował Statut Kaliski, jednak w tym przypadku najważniejszym dokumentem był ten, wydany przez J. Zamoyskiego. Przywilej nie tylko dawał możliwości budowlane, ale też prawo do kreowania wspólnoty żydowskiej, budowy synagogi i gwarantował sprzyjanie przez władze rozwojowi handlu i rzemiosła (Piechotkowie, 1999). W związku z tym, tzw. dzielnica żydowska stopniowo obejmowała coraz większy teren: dzisiejszą ulicę Pereca i Rynek Solny - symetryczny do Rynku Wodnego które razem wyznaczają jedną z najważniejszych osi miasta. Należy jednak wyjaśnić, że pojęcie "dzielnica żydowska" jest stosowane - zarówno w niniejszej pracy, jak i w wcześniejszych publikacjach - umownie. Zgodnie z przywilejem osiedleńczym J. Zamoyski oddał ul. Szewską i północną pierzeję Rynku Solnego do użytku Żydom. Jednak obszar ten nie był wydzielony, nie wyróżniał się odrębnym stylem czy układem urbanistycznym od pozostałych zabudowań w centrum miasta. 
Przybywający do Zamościa spotykali się z wyjątkową na tle europejskim sytuacją kształtowania się ściśle zaplanowanej i dynamicznie rozwijającej się przestrzeni miejskiej. Pomimo, że niepokoje na pozostałych terenach prowadziły do zmniejszenia tempa budowlanego w pierwszej ćwierci wieku XVII (Kozakiewicz, 1978), to migranci przyczyniali się do zwiększania dynamiki powstawania przestrzeni urbanistycznej. Żydzi budowali bowiem nowe domy przy ulicy Żydowskiej (współczesnej ul. Ludwika Zamenhofa), a następnie: założony na przełomie XVI i XVII w. cmentarz żydowski przy ulicy Partyzantów, cheder (szkoła dla chłopców), mykwy i synagogę, będącą głównym tematem niniejszego artykułu.

O NIE-ŻYDOWSKIEJ TOŻSAMOŚCI ZAMOJSKIEJ ARCHITEKTURY.

Architektura, którą można określić jako żydowską była względnie spójna z pozostałymi budowlami powstałymi w tym czasie. Stylistycznie jest bowiem - jak zwraca uwagę Helena Kozakiewicz - na pograniczu późnego renesansu z wczesnym barokiem (Kozakiewicz, 1978). W ten sam sposób można sklasyfikować większość zabudowań Zamościa, w tym Ratusz Miejski, co jeszcze silniej podkreśla brak izolacji społeczności żydowskiej tego czasu.

Budynki w obszarze nazywanym umownie dzielnicą żydowską $\mathrm{w}$ większości miały formę parterowych, dwutraktowych domów drewnianych. Murowanych domów było niewiele. Na przełomie XVII i XVIII istniało zaledwie 7 kamienic, w tym cztery z nich zostały wybudowane w obrębie rynku (Baranowscy, 1967).

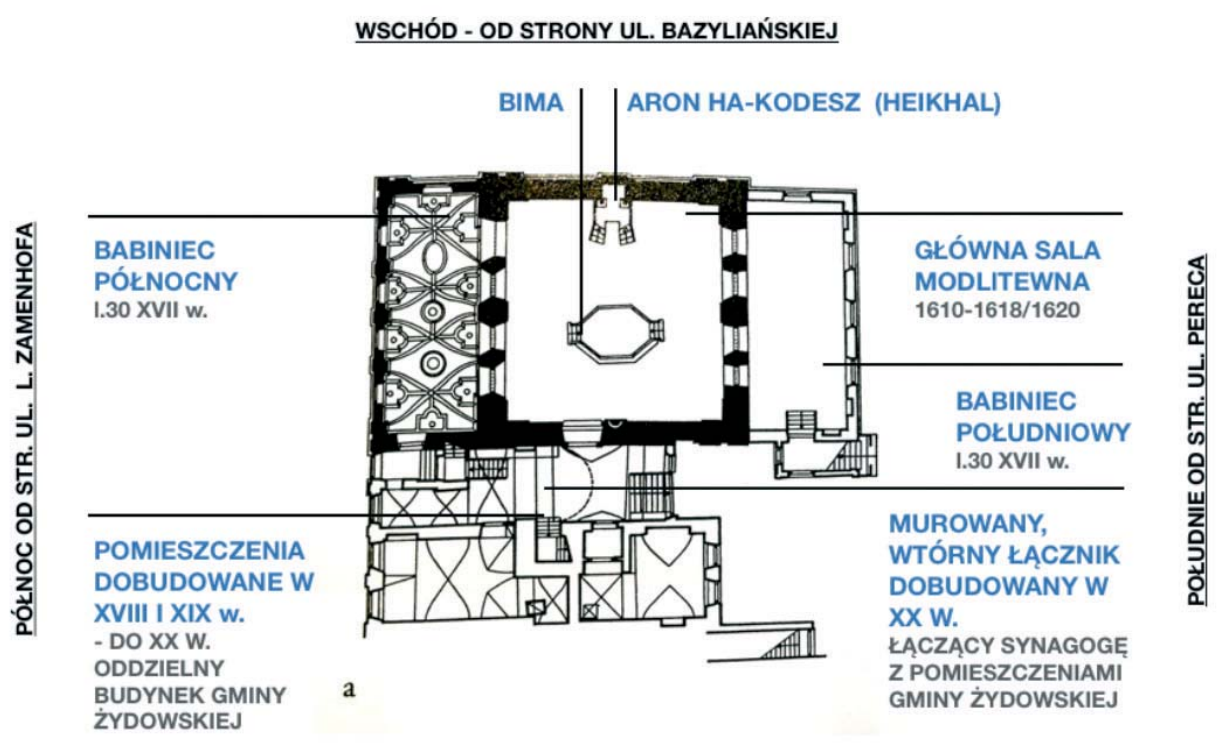

ZACHÓD - OD STRONY RYNKU SOLNEGO

Rysunek 1. Plan przyziemia Synagogi w Zamościu z uwzględnieniem funkcji najważniejszych elementów przestrzeni architektonicznej.

Źródło: opracowanie własne.

Ogrody Nauk i Sztuk nR 2021 (11) 
Także bóżnica charakteryzuje się silną spójnością stylistyczną z pozostałymi zabudowaniami. Synagoga została zrealizowana, jako obiekt jednoprzestrzenny (rys. 1), z niezachowaną piwnica, która została zasypana po II wojnie światowej. W XVII w. - prawdopodobnie w latach 30-tych (Kuwałek, Litwin, 2011) - od strony północnej i południowej dobudowano do obiektu dwa babińce: aneksy przeznaczone dla kobiet.

Jej forma ulegała zmianom na przestrzeni lat, jednak w dalszym ciagu pozostawała ona stylistycznie spójna z architekturą Zamościa. W wieku XVIII synagoga została poddana licznym przebudowom, wśród których wyliczyć można dobudowanie przedsionka od zachodu. Przylega on do sąsiadującej z obiektem kamienicy - Domu Kahalnego przy ulicy Ludwika Zamenhofa 11. Same kamienice, które z synagogą połączył przedsionek prawdopodobnie, tak samo jak synagoga, zostały zbudowane wcześniej, w wieku XVII. Dobudowa przedsionka od strony zachodniej wynikała z adaptacji dwóch sąsiadujących kamienic na cheder (Trzciński, 1990).

Zmiany w tej części, aktualnie połączonej z synagogą przejściem, zachodziły również w wieku XIX i po II wojnie światowej, a ich dokładna historia i funkcja nie jest znana. Wiadomo, że początkowo synagoga była odrębnym budynkiem, oddzielonym od zabudowań od strony zachodniej. Część ta należała do gminy żydowskiej i pełniła różne funkcje: pomieszczeń administracyjnych, mykwy (przed budowa, w połowie XVIII w. mykwy przy ulicy Ludwika Zamenhofa 3), sal zajęciowych użytkowanych przez szkoły religijne (cheder), w tym Jesziwę, czy mieszkań dla ważnych przedstawicieli gminy.

W tym okresie, tj. w wieku XVIII, została zlikwidowana również attyka. Zmieniony został również dach na dwuspadowy z naczółkiem (półszczytem dolnym), zaś do babińców dobudowano drugą kondygnację (Trzciński, 1990). Tym samym okna po stronie północnej i południowej, które w wieku XVII wychodziły bezpośrednio na podwórze (podobnie jak jest to współcześnie), stały się otworami w ścianie działowej między babińcami a salą główną.

Dwuspadowy dach umożliwił stworzenie strychu nad salą główna, na którym, według przekazów ustnych, po wojnie odnaleziono książki. Nie wiadomo jednak, w którym dokładnie miejscu znajdowało się wejście na poddasze.

W XX w. dążono do rekonstrukcji wcześniejszego wyglądu budynku. Pomiędzy rokiem 1948 a 1950 dobudowano - zniszczony podczas wojny - jednokondygnacyjny babiniec południowy oraz zlikwidowano piętro nad babińcem północnym (Kuwałek, Litwin, 2011). Zmianom uległy, w latach 1967-1972, elewacje i zrealizowane zostały attyki zakrywające dach, stylistycznie nawiązujące do miejscowych kamienic budowanych od XVI do XVII wieku (Bergman, Jagielski, 1996). Oznacza to, że zrekonstruowana attyka ma, zapewne, inną formę niż pierwotna, której wygląd nie jest znany.

Mimo próby przywrócenia synagodze pierwotnej, wizualnej tożsamości, budynek ten nigdy nie uzyskał swej pierwotnej funkcji, utraconej podczas II Wojny Światowej. Od maja 2005 roku, budynek pełni funkcję muzeum i ośrodka kultury (Centrum „Synagoga") będąc własnością Fundacji Ochrony Dziedzictwa Żydowskiego.

\section{ULOKOWANIE SYNAGOGI W PRZESTRZENI MIEJSKIEJ}

We współczesnych interdyscyplinarnych badaniach nad architekturą kładzie się szczególny nacisk na symboliczne znaczenie przestrzeni miejskiej. Aspekt ten jest 
szczególnie ważny w kontekście obiektów sakralnych czy realizacji, przez które dąży się do upodmiotowienia danej nacji czy mniejszości. Zjawisko to ukazują późniejsze, ale kontrastowe koncepcje, takie jak niezrealizowane bulwary nadwiślańskie według A. Langego, które miały stanowić kontrpropozycję do budowy rosyjskiej, monumentalnej cerkwi na Placu Saskim, będąc jednoczesnym wyrazem wiary w upadek Cesarstwa Rosyjskiego po rewolucji rosyjskiej i pomysłem na "uzdrowienie Warszawy" (Lange, 1906). Można wymienić także złożoną problematykę lokalizacji Nowej Synagogi w Częstochowie, czy koncepcję S. Wyspiańskiego i W. Ekielskiego o jeszcze innym charakterze: Akropolis na Wawelu. Przykłady te wskazują na niezwykle silne znaczenie ulokowania obiektu w danej przestrzeni miasta, które jest kluczowe do zrozumienia charakteru nie tylko samej architektury, ale też sytuacji i klimatu społecznego, w którym dzieło powstaje.

W Zamościu, oprócz niezwykłej sytuacji społecznej, sam architektoniczny zamysł na siatkę miasta był wyjątkowy na tle pozostałych ośrodków europejskich. Zakładano, że przestrzeń nie będzie wernakularna, a zostanie stworzona przez jednego architekta, według jednej koncepcji. Zamość został zaprojektowany na rzucie bastionowego pięcioboku, który można podzielić na dwa segmenty. Pierwszy z nich wydziela się od strony wschodniej, jako prostokątna przestrzeń właściwej części miejskiej o szachownicowym układzie ulic z Rynkiem Głównym i pomocniczymi: Wodnym i Solnym. To właśnie w tym obszarze ulokowane są najważniejsze zabudowania, w tym synagoga.

Drugi segment został zaprojektowany od strony zachodniej, przylegając do miasta dłuższym bokiem. Był przeznaczony na przestrzeń rezydencjonalną z Pałacem Kanclerskim (Zamoyskich), ukończonym w 1581 r. i przebudowanym w latach 17441745 (Tatarkiewicz, 1966, 328). Bernardo Morando tworząc ów plan miasta wydzielił dwie główne osie kompozycyjne - najważniejsze ciągi komunikacyjne. Ich analiza umożliwia zrozumienie problematyki lokacji zabudowań architektury żydowskiej, ale przede wszystkim pozycji społeczności żydowskiej.

Rozrastająca się dzielnica żydowska szybko objęła swoim zasięgiem ulicę Horodelską (w źródłach nazywaną Żydowską dziś ul. Zamenhofa), Szewską oraz Rynek Solny (Baranowscy, 1967) - jeden z dwóch najistotniejszych, obok Rynku Wielkiego, placów w strukturze miasta idealnego według Bernardo Morando. Jednak to właśnie, nigdy nieskończony, Rynek Solny sprawował, jak się zdaje, dużo ważniejszą funkcję - przestrzeni handlowej. Tym samym wnioskować można, że społeczność żydowska zamieszkująca $\mathrm{w}$ tym czasie na terenie Zamościa nie była izolowana: współistniejąc $\mathrm{w}$ bezpośrednim centrum renesansowego miasta, a nawet czerpiąc w swej architekturze z wzorów obecnych w tamtejszych kościołach chrześcijańskich. Nie wiadomo również o przepisach, które ograniczałyby Żydom zamieszkiwanie w obrębie centrum miasta, co odróżniało Zamość od miast takich, jak Krasnystaw, Urzędów, Lublin, Tarnogóra czy Wąwolnica (Trzciński, 1990, 7). Wskazuje na to ulokowanie samej synagogi, współcześnie obwiedzionej z trzech stron ulicami L. Zamenhofa (wcześniej ul. Żydowska), Bazyliańską i Pereca. Można przytoczyć pomiary - dokonane na rzecz niniejszej analizy - oddalenia w linii prostej, synagogi od najważniejszych obiektów w Zamościu: 90 m od Rynku Solnego, 118 m od Ratusza Miejskiego, 150 m od centralnej części placu Rynku Wielkiego, 250 m od Rynku Wod-

Ogrody Nauk i Sztuk nR 2021 (11) 
nego, 290 m od kolegiaty pw. św. Tomasza Apostoła, czy niespełna 380 m od Pałacu Zamoyskich.

\section{CHRZEŚCIJAŃSKa, SEFARDYJSKA CZY ASZKENAZYJSKA STYLISTYKA BOŻNICY?}

Układ przestrzenny synagog, podobnie jak w przypadku kościołów katolickich, podlega pewnym regułom religijnym, według których najważniejszą jest główna sala modlitewna z umieszczonym na wschodzie aron ha-kodesz - inaczej Heikhal (Piechotkowie, 1999) - przeznaczonym do przechowywania zwojów Tory. Synagoga w Zamościu wpisuje się w charakterystyczny, dość spójny i obecny na terenie całej Rzeczypospolitej do końca XVIII w. nurt synagog judaizmu przedreformacyjnego, który został przerwany dopiero po około 200 latach od powstania przez wyklarowanie się trzech głównych nurtów: judaizmu ortodoksyjnego, chasydyzmu i judaizmu reformowanego (Bergman, Jagielski, 1996).

Pierwotnie synagogi powstające $\mathrm{w}$ tym okresie były budynkami jednoprzestrzennymi, czego przykładem jest bożnica w Szydłowie. Taki zamysł na przestrzeń synagogalną został uwzględniony również w projekcie orientowanej synagogi w Zamościu, wybudowanej w latach 1610-1618 (Kuwałek, Litwin, 2011) lub 1610-1620 (Bergman, Jagielski, 1996). W tej synagodze sala główna została zaplanowana na rzucie nieco wydłużonego kwadratu.

Centralnym elementem wnętrza bożnicy była nieistniejąca, zniszczona podczas II wojny światowej, ale znana z licznych fotografii ośmiokątna, altanowa bima (in. podwyższenie, tewa, belemer), (rys. 1). Jak już w 1999 r. przypuszczali Maria i Kazimierz Piechotkowie, bima mogła zostać zbudowana później niż sama sala modlitewna. (Piechotkowie, 1999). Powstała bowiem w XVIII w., a jej sponsorem był Samuel Barzel (Kuwałek, Litwin, 2011). Należy dodać, że ułożenie bimy na środku głównej sali modlitewnej było charakterystycznym zabiegiem na ziemiach ówczesnej Rzeczypospolitej, ale także w średniowiecznych synagogach aszkenazyjskich i sefardyjskich (Kuwałek, Litwin, 2011).

Pozostanie przy takim układzie - który można nazwać w sposób uproszczony „układem tradycyjnym” - wskazuje, iż wspólnota zamoyska nie dostosowała się do nowszych zaleceń znanego, sefardyjskiego uczonego Józefa Karo. Wskazywał on na obowiązek umieszczenia bimy w zachodnim obszarze sali głównej, a tym samym po przeciwnej stronie niż aron ha-kodesz (Kuwałek, Litwin, 2011). Wynika z tego, że - mimo, iż w licznych przewodnikach (głównie turystycznych) zamojska synagoga „reklamowana jest” jako obiekt o wzorach z Półwyspu Iberyjskiego - bożnica faktycznie pozbawiona jest cech sefardyjskich. Takie uzasadnienia są jednak niezwykle popularne nie tylko w kontekście renesansowej bożnicy, która jest przedmiotem tej pracy, ale też nurtu mauretańskiego rozwijającego się w XIX i na początku XX wieku. Za odrzuceniem tak silnie rozpowszechnionej teorii ciąłości tradycji hiszpańskiej nie w kontekście zamojskiej bożnicy, ale architektur w ogóle - opowiada się Eleonora Bergman, polemizująca z Georgem Loukomskim (Bergman, 2004). Tezy te implikuje się do niniejszej analizy synagogi w Zamościu, wskazując na potrzebę zmiany dyskursu jej analizy, także w materiałach popularnonaukowych i przewodnikach.

Należy uzupełnić niniejszy wątek o problematykę dekoracji elewacji budynku. Wskazują one na istnienie cech wspólnych z charakterystyczną zabudową renesan- 
sową na terenie Zamościa czy Lublina, nie zaś z architekturą hiszpańską. Jednak budynek ten ma więcej cech wspólnych z elewacjami zabudowań kościelnych, niż z powstającą w tym samym czasie zabudową świecką. Obiekt ten, podobnie jak zabudowania chrześcijańskie, ma zdecydowanie mniej dekoracyjne i mniej ekspresyjne elewacje niż budynki takie, jak niezachowane domy lubelskie, kamienica Książęca w Zamościu, czy kamienica Pod św. Mikołajem i Krzysztofem w Kazimierzu Dolnym. Władysław Tatarkiewicz, nie opisując samych synagog, wskazuje terytorialne źródła obu tendencji; „,czystych", włoskich wpływów na architekturę sakralną i wpływów lwowskich na architekturę świecką (Tatarkiewicz, 1966).

\section{DEKORACJE WNĘTRZA SYNAGOGI - TYP KALISKO-LUBELSKI}

W wieku XVI, jak i na początku wieku XVII w zabudowaniach synagogalnych nie stosowano bogatych dekoracji wnętrza. Ściany pozostawiono gładkie a dekoracja aron ha-kodesz ujmowana była $\mathrm{w}$ proste, prawie zawsze kamienne obramowanie. Przykładami takich bożnic jest synagoga w Opatowie, Złotej Róży we Lwowie, w Pińczowie, Szydłowie, na Kazimierzu w Krakowie, czy w Starej. Zmiana w dekoracjach wnętrza zachodzi w pierwszej ćwierci XVII w. (Piechotkowie, 1999).

Jak wspomniano powyżej, rzut synagogi w Zamościu wpisuje się we względnie charakterystyczna, nie-sefardyjską zabudowę synagogalną na terenach Polski. Wyróżnikiem tej budowli, oprócz jej niezwykle dobrego zachowania, jest jej spójność z pozostałymi zabudowaniami na terenie miasta. Dotyczy to jednak nie tylko synagogi, ale też domów w dzielnicy żydowskiej, które formą elewacji zewnętrznych i układem wnętrza były zgodne ze schematem zabudowy mieszczańskiej siedemnastowiecznego Zamościa. Jednak - jak wskazują Z. i J. Baranowscy - dekoracja stiukowa we wnętrzu synagogi, wyróżnia się szczególnie wysokim poziomem artystycznym. Nie da się atrybuować ich konkretnemu twórcy, co wynika ze zbyt małej wiedzy o działalności muratorów na terenie miasta (Baranowscy, 1967). Można jednak rozważać autorstwo warsztatu Gocmana, Jana Wolffa lub Jana Jaroszewicza.

Fakt barwienia sztukaterii można uznać za odstępstwo od dekoracji realizowanych w typie kalisko-lubelskim. Za cechy tej stylistyki uważa się plastyczność, kompozycję zamknięta, symetryczność figur geometrycznych tworzących sieć, a także brak barwienia, co nie zostało spełnione w zamojskiej bożnicy. Mimo tego, spełnia ona wszystkie pozostałe kryteria dekoracji sklepień $\mathrm{w}$ ramach tego nurtu.

Pierwotnych źródeł tego typu dekoracji można doszukiwać się w sklepieniach gotyckich: traktując sztukaterię jako reinterpretację wzorów późnego średniowiecza. Można wnioskować, że wciąż obecna na ziemiach polskich tradycja gotycka, którą widać w stylu kaliskim, mogła stać się asumptem do wzmożonej popularności sztukaterii geometrycznych $\mathrm{w}$ sklepieniach renesansowych budowli. Tendencja ta została jednak zapoczątkowana we Włoszech, gdzie sztukaterie miały nieco inny charakter: będąc podporządkowane malarstwu, nie stanowiąc głównego elementu dekoracyjnego.

Z uwagi na brak dekoracji malarskich w typie kalisko-lubelskim można sądzić, iż to właśnie tradycja gotycka wraz z, na co zwraca uwagę Władysław Tatarkiewicz, prostszym wykonaniem (tj. brakiem obowiązku zatrudniania malarza, a jedynie sztukatora) sprawiła, że ten typ dekoracji stał się tak powszechny w tym rejonie (Tatarkie-

Ogrody Nauk i Sztuk nR 2021 (11) 
wicz, 1966). W tym okresie - pod koniec XVI i na początku XVII wieku - sztukaterie geometryczne były powszechnie stosowane na terenie Europy, m.in. na terenie całych Włoch i w poszczególnych miastach: w Pradze (cf. St. Salvator, Czechy) czy Würzburgu (Ratusz Miejski, Niemcy). Wynikało to ze zmniejszającej się popularności stropów drewnianych i nieprzyjęciu się, jeszcze, malowideł na przestrzeni sufitów (Tatarkiewicz, 1966).

Co ważne, ponieważ wskazuje na jeszcze starsze źródła tej dekoracji, we Włoszech inspiracją do tworzenia sztukaterii stały się budowle starożytnego Rzymu, a wśród nich sklepienia w katakumbach św. Sebastiana w Rzymie, Domus Aurea (tzw. Złoty Dom Nerona) w Rzymie, czy w Basilica Sotterranea di Porta Maggiore (Lanzetta, D'Anna, 2011).

W przypadku polskiej architektury, podobnie, jak ulokowanie synagogi, podobieństwa w dekoracji wskazują na korelację i współistnienie społeczności chrześcijańskiej ze społecznością żydowską. Należy wskazać, co jak się zdaje zasługuje na szczególną uwagę, że wzory dekoracyjne typu kalisko-lubelskiego, jak i cechy elewacji, są charakterystyczne przede wszystkim dla zabudowań kościelnych. Pojawiały się one również w kamienicach prywatnych, szczególnie w ramach tzw. grupy krakowskiej, zapoczątkowanej przez Giovanniego Trevano (Tatarkiewicz, 1966). Jednak zdobienia te były dużo prostsze; z prostymi listwami, uproszczonymi układami geometrycznymi i o mniejszym znaczeniu niż liczne dekoracje kościelne w Zamościu, czy Lublinie.

Podobieństw $\mathrm{w}$ dekoracji sztukateryjnej ze zdobieniami synagogi można doszukiwać się w licznych kościołach z pierwszej połowy XVII wieku: św. Jakuba w Sandomierzu, św. Trójcy w Radzyniu, farnym w Kazimierzu Dolnym, Wniebowzięcia Najświętszej Marii Panny w Uchaniach, czy pobernardyńskim w Drui. Kluczowe są również dekoracje sklepienia w Katedrze Zmartwychwstania Pańskiego i św. Tomasza Apostoła w Zamościu, która oddalona jest od synagogi o 290 metrów w linii prostej. Kolegiata ta nie została, co prawda rozplanowana na rzucie przestrzennym charakterystycznym dla typu kalisko-lubelskiego, jednak stanowiła ważny wzór dekoracyjny, metaforycznie „dając początek” sztukateriom geometrycznym.

\section{PoDsumowANIE I WNIOSKI}

Przedreformacyjna architektura synagogalna w końcu XVI i początku XVII w. jest „uwikłana” w szeroki kontekst: nie tylko epoki, ale też problemów budownictwa mniejszości religijnych i narodowych. Opisane w niniejszej pracy obiekty powstały w tzw. złotym wieku Żydów Polskich (Piechotkowie, 2017, 81), w którym dotychczas nieformalne i niewielkie gminy przetransformułowały się $\mathrm{w}$ zorganizowane samorządy. Do rozwoju samorządowego, a także kultury i sztuki judaizmu przyczyniła się wolność decyzyjna i nadawane w ciagu XVI w. swobody w obszarze prawnym i religijnym. Istotne znaczenie miała także dogodna sytuacja ekonomiczna.

Równocześnie przełom XVIiXVII w. byłczasem kreowania nowychukładów i form w obrębie budownictwa żydowskiego w Polsce. Jest to odwrotną tendencją od krajów Europy Zachodniej, z których wysiedlono społeczność żydowska, a poszukiwanie nowych rozwiązań architektonicznych uległo zatrzymaniu. Należy jednak uwzględnić, że mimo owej dynamizacji rozwoju form nie utworzyły się wyraźne nurty stylistyczne a schematy kompozycyjne były stosowane przede wszystkim we wnętrzach świątyń. 
Widoczne to jest w projektowaniu rozmaitych układów sali głównej. Wśród nich można wymienić typy takie jak: pozbawione podpór wewnętrznych $\mathrm{z}$ jedną nawą $\mathrm{z}$ bimą w formie wieży czy według schematu dziewięciopolowego/czterofilarowego (Piechotkowie, 2017). Zastosowanie poszczególnej koncepcji układu przestrzennego determinowało dekorację pozostałych elementów, a szczególnie formy aron ha-kodesz (zdecydowanie większe i bogatsze w salach głównych z wieżą-bimą). Różnice widoczne są także $\mathrm{w}$ układach babińców, które występują samodzielnie lub nad sienią. Jednolitość wzorów była zachowywana tak naprawdę tylko w układzie bimy, która zawsze była umieszczana na środku głównej sali modlitewnej.

Synagogę w Zamościu cechuje jeszcze silniejsza odrębność od świątyń z pozostałych terenów Rzeczpospolitej. Była ona pierwszą znaną bożnicą w Polsce, w której porzucono skromny i surowy wygląd elewacji (Piechotkowie, 2017) - w innych miastach narzucany przez przepisy władz kościelnych. Co ważne w budowli widoczne są stylistyczne nawiązania do cech architektury kościelnej i świeckiej Lubelszczyzny. Widoczne jest to przede wszystkim w podziale elewacji za pomocą par pilastrów.

W ramach podsumowania niniejszego artykułu należy zwrócić uwagę na kilka wniosków metodologicznych i problemów teoretycznych. Jako pierwsze chcę wskazać na potrzebę wdrażania dyskursu krytycznego wobec silnie rozpowszechnionej teorii ciągłości tradycji hiszpańskiej, czego - w kontekście architektury mauretańskiej - podejmowała się już Eleonora Bergman. Jest to szczególnie ważne, ponieważ tezy o sefardyjskości zamojskiego budownictwa judaizmu z publikacji popularnonaukowych i przewodników przepisywane są do literatury naukowej. Prawdziwym wzorem stylistycznym zdaje się być - oprócz wcześniejszych synagog - architektura kościelna z obszaru Ordynacji Zamojskiej. Świadczy to o przenikaniu się detalu i przesuwaniu granicy typu kalisko-lubelskiego, który jednak, jak do tej pory, w kontekście architektury synagogalnej nie został opisany.

Wnioskiem wysuniętym po analizie synagog wschodniej Polski, jest potrzeba ich dalszego badania i dostrzeżenia potencjału architektury tworzonej przez mniejszości narodowe i wyznaniowe. Stanowi to dyrektywę metodologiczna, w ramach której zakłada się, że $\mathrm{w}$ historii architektury priorytetem nie jest tylko uwzględnianie ergonomiczności, ale równocześnie warunków społeczno-kulturowych, w których budowla istnieje. Oznacza to potrzebę interdyscyplinarnej analizy dzieła sztuki, w której uwzględnia się nie tylko opis formy, ale interpretację znaczenia, które metaforycznie ma „nosic" realizowany obiekt.

\section{BibLIOGRAFIA}

[1] Baranowski, J., Z. (1967). Dzielnica żydowska i synagogi w Zamościu. Biuletyn ŻIH, 63, 41-56.

[2] Bergman, E. (2004). Nurt mauretaníski w architekturze synagog Europy Środkowo- Wschodniej w XIX i na początku XX w. Warszawa: Wydawnictwo Neriton.

[3] Bergman, E., Jagielski, J. (1996). Zachowane synagogi i domy modlitwy w Polsce. Katalog. Warszawa: Żydowski Instytut Historyczny.

[4] Danilewicz, J. (2005). Bożnica staromiejska w Zamościu, Zamojski Kwartalnik Kulturalny, 5, (1-2), 143-150.

[5] Fornal, M. (1999). Przyczynek do historii bóżnic na Zamojszczyźnie. Zamojski Kwartalnik Kulturalny, (3-4), 71-76.

[6] Herbst, S. (1954). Zamość. Warszawa: Budownictwo i Architektura.

[7] Kozakiewicz, H. (1978). Renesans i manieryzm w Polsce. Warszawa: Auriga.

[8] Kuwałek, R., Litwin W. (2011). Rewitalizacja renesansowej synagogi w Zamościu -na potrzeby Szlaku Chasydzkiego oraz lokalnej społeczności., Warszawa: FundacjaOchrony Dziedzictwa Żydowskiego.

Ogrody Nauk i Sztuk NR 2021 (11) 
[9] Lange, A. (1906). Marzenie warszawskie, Świat,(5), 40-41.

[10] Lanzetta, D., D’Anna N. (2011). Roma orfica e dionisiaca nella Basilica "pitagorica"di Porta Maggiore, Rzym: Simmetria Edizioni.

[11] Litwin, W., Szabłowska-Zaremba, M., Żurek, S. (2012). Żydzi w Zamościu i na Zamojszczyźnie. Historia, kultura, literatura., Lublin: Towarzystwo Naukowe Katolickiego Uniwersytetu Lubelskiego im. Jana Pawła II.

[12] Łupienko, A., Zabłocka-Kos, A. (2019). Architektura w mieście. Architektura dla miasta, Warszawa: Instytut Historii PAN.

[13] Matyjaszek, K. (2019). Produkcja przestrzeni żydowskiej w dawnej i wspótczesnej Polsce, Kraków: Universitas.

[14] Michalski, M. (2015). Architecture of Judaism on the examples of synagogues in the17th- and the 18th-centuries in Poland. Architectus, (3), 43.

[15] Morgensztern, J. (1961). Uwagi o Żydach sefardyjskich w Zamościu w latach1588-1650. Biuletyn ŻIH, 38.

[16] Morgensztern, J. (1962). Osadnictwo Żydów w Zamościu na przełomie XVI i XVII w.. Biuletyn ŻIH,(43-44).

[17] Piechotek, M., K. (1999). Bramy Nieba. Bóżnice murowane na ziemiach dawnej Rzeczypospolitej. Warszawa: Wydawnictwo Krupski i S-ka.

[18] Piechotek, M., K. (2004). Oppidum Judaeorum: Żydzi w przestrzeni miejskiej dawnej Rzeczypospolitej. Warszawa: Wydawnictwo Krupski i S-ka.

[19] Przegoń, W., Żygawski, J. (2018). Kartograficzne zamostiana. Zamość: Archiwum Panśstwowe w Zamościu.

[20] Sadurska, A. (1965). W сіепiu Panteonu: o sztuce starożytnego Rzymu. Warszawa: Wiedza Powszechna.

[21] Serafin-Sochańska, Z. (1938). Zamość. Zamość: Wydawnictwo Koła Miłośników Książki.

[22] Targońska, E. (2005). Mała Padwa Północy. Archiwwariusz Zamojski, 137-140.

[23] Tatarkiewicz, W. (1966). Turniej klasyków w Zamościu W: W., Tatarkiewicz (red.), O sztuce Polskiej XVII i XVIII (ss. 326-339). Warszawa: Państwowe Wydawnictwo Naukowe.

[24] Tatarkiewicz, W. (1966). Typ lubelski i typ kaliski w architekturze XVII w. W:W., Tatarkiewicz (red.), O sztuce Polskiej XVII i XVIII (ss. 108-149). Warszawa: Państwowe Wydawnictwo Naukowe.

[25] Tomkowicz, S. (1929). Ordynaci Zamoyscy i sztuka. Teka Zamojska,(3).

[26] Zajczyk, S. (1939). Muratorzy zamojscy. Biuletyn Historii Sztuki i Kultury, t. VII.

[27] Zdrojewska, M. (1960). Bożnica w Zamościu. Turysta, (4), 12-13. 